\title{
ATP-Sensitive $\mathrm{K}^{+}$Channels Are Gradually Recruited in the Vasodepressor Response to Adenosine in Spinally-Anesthetized Dogs
}

\author{
Kensuke Orito, Keisuke Satoh and Norio Taira \\ Department of Pharmacology, Tohoku University School of Medicine, Sendai 980, Japan \\ Received August 14, 1992 Accepted September 16, 1992
}

\begin{abstract}
Vasodepressor mechanisms of adenosine were investigated in spinally-anesthetized dogs. An i.v.-infusion of adenosine $(0.1-10 \mu \mathrm{mol} / \mathrm{kg} / \mathrm{min})$ caused a slowly developing and sustained decrease in blood pressure (BP). This vasodepression was antagonized by glibenclamide, a blocker of ATP-sensitive $\mathrm{K}^{+}\left(\mathrm{K}_{\mathrm{ATP}}\right)$ channels. On the other hand, a transient decrease in BP caused by a single bolus i.v.injection of adenosine was not antagonized by glibenclamide in our previous study. These results suggested that the opening of $\mathrm{K}_{\mathrm{ATP}}$ channels is gradually recruited in the vasodepressor mechanisms for adenosine-induced sustained vasodepression.
\end{abstract}

Keywords: Adenosine-induced vasodepression, ATP-sensitive $\mathrm{K}^{+}$channel, Glibenclamide

It has been accepted that vasodilatation or vasodepression caused by adenosine is mediated by adenosine $A_{2}$-receptors $(1,2)$ and that an increase in cAMP plays an important role in this process $(3,4)$. Recently, Belloni and Hintze (5) suggested that opening of ATPsensitive $\mathrm{K}^{+}\left(\mathrm{K}_{\mathrm{ATP}}\right)$ channels was involved in the vasodepressor response to adenosine in anesthetized dogs; the response was antagonized by glibenclamide, a blocker of $\mathrm{K}_{\mathrm{ATP}}$ channels (6). Our previous study, however, failed to demonstrate the involvement of $\mathrm{K}_{\mathrm{ATP}}$ channels in the transient decrease in blood pressure (BP) caused by a single bolus i.v.-injection in spinally-anesthetized dogs; the decrease in BP caused by the adenosine injection was not antagonized by glibenclamide (7). On the other hand, the vasodepressor response to YT-146, a selective adenosine $\mathrm{A}_{2}$-receptor agonist $(8,9)$, which developed slowly and was sustained, was antagonized by glibenclamide in the same study (7). Thus, it was hypothesized that the opening of $K_{\mathrm{ATP}}$ channels would be gradually recruited in the vasodepressor mechanism of adenosine- $\mathrm{A}_{2}$-receptormediated vasodepression (7). To test this hypothesis we investigated how the vasodepressor response to i.v.-infusion of adenosine would be modified by glibenclamide.

Fourteen young mongrel dogs of either sex, weighing 7 to $14 \mathrm{~kg}$, were anesthetized with sodium pentobarbital
$(30 \mathrm{mg} / \mathrm{kg}$, i.v.). Spinal anesthesia was induced with an intra-cistemal injection of dibucaine hydrochloride solution (about $0.2 \mathrm{ml} / \mathrm{kg}$ ) after i.v.-injection of nadolol $(100 \mu \mathrm{g} / \mathrm{kg})$ and atropine $(1 \mathrm{mg} / \mathrm{kg})$. Bilateral vagotomy was performed. Animals were respired with room air in a tidal volume of $20 \mathrm{ml} / \mathrm{kg}$ at $18 \mathrm{breaths} / \mathrm{min}$ by the use of a respirator (Shinano, Model SN-480-3). Body temperature was maintained at about $39^{\circ} \mathrm{C}$ with a heating device. $\mathrm{BP}$ was measured at the right femoral artery with a pressure transducer (Statham, P-50) and heart rate (HR) was measured with a cardiotachometer (San-ei, 1321) triggered by arterial pressure pulses.

The BP of spinally-anesthetized animals was maintained at an elevated level by i.v.-infusion of noradrenaline $(0.5 \mu \mathrm{g} / \mathrm{kg} / \mathrm{min})$ by the use of an infusion pump (Harvard Apparatus, Model 600-00). Five animals were given the vehicle ( $100 \% N, N$-dimethylformamide, control), another five glibenclamide, and an additional four glibenclamide plus theophylline. Before receiving adenosine infusion, all the animals were given dipyridamole $(100 \mu \mathrm{g} / \mathrm{kg}, \mathrm{i} . \mathrm{v}$.), a potentiator of adenosine (10). Otherwise, i.v.-infusions of adenosine failed to produce sizable decreases in BP. An infusion pump (Terumo, STC-521) was used for the continuous i.v.-infusion of adenosine. Infusion rates were increased when the BP responses reached a nadir.

Glibenclamide (Yamanouchi), nadolol (Squibb), adeno- 
sine (Sigma), theophylline (Sigma), (-)-noradrenaline base (Sigma), dibucaine hydrochloride $(0.3 \%$ hyperbaric solution in ampoules, Teikoku Chemical) and atropine sulfate (Wako) were used. Glibenclamide was dissolved in $0.5 \mathrm{ml}$ of $100 \% \mathrm{~N}, \mathrm{~N}$-dimethylformamide at the desired concentrations. Nadolol and (-)-noradrenaline base were dissolved in $0.1 \mathrm{~N} \mathrm{HCl}$. Other compounds were dissolved and diluted with $0.9 \%$ saline to the desired concentrations.

Changes in MBP were expressed as percentages of its basal values obtained before infusion of adenosine. $E D_{50}$ values for adenosine were obtained by computerfitting of the dose-response curves for the change in MBP to a sigmoid function by a non-linear least squares routine. The statistical significance of differences between $E D_{50}$ values was analyzed with Student's $t$-test. A P value smaller than 0.05 was considered to indicate a significant difference.

The average values of MBP and HR for fourteen spinally-anesthetized dogs, whose MBPs were maintained at an clevated level with i.v.-infusion of noradrenaline, were $176 \pm 4 \mathrm{mmHg}$ and $149 \pm 6$ beats $/ \mathrm{min}$, respectively. Glibenclamide or theophylline per se had no effect on MBP and $\mathrm{HR}$.

In control dogs, infusion of adenosine $(0.1-10$ $\mu \mathrm{mol} / \mathrm{kg} / \mathrm{min}$ ) caused slowly developing decreases in $\mathrm{BP}$ and $\mathrm{HR}$, and MBP was lowered to about $46 \mathrm{mmHg}$ and $\mathrm{HR}$ to 116 beats/min at the highest infusion rate $(10 \mu \mathrm{mol} / \mathrm{kg} / \mathrm{min})$. One of such experiments is shown in Fig. 1, and the dose-response curve for the decrease in $\mathrm{MBP}$ is shown in Fig. 2. In dogs that received glibenclamide $(6 \mu \mathrm{mol} / \mathrm{kg}$, i.v. $)$, the dose-response curve for the decrease in MBP underwent a rightward shift (Fig. 2); the $\mathrm{ED}_{50}$ value increased about 6-fold (1.3 to $7.5 \mu \mathrm{mol} / \mathrm{kg} / \mathrm{min}$ ). A further rightward shift of the dose-response curve for the decrease in MBP occurred in dogs that received glibenclamide $(6 \mu \mathrm{mol} / \mathrm{kg}$, i.v.) plus theophylline ( $30 \mu \mathrm{mol} / \mathrm{kg}$, i.v.) (Fig. 2); the $\mathrm{ED}_{50}$ value increased about 33-fold (1.3 to 42.6 $\mu \mathrm{mol} / \mathrm{kg} / \mathrm{min})$. Decreases in HR to adenosine infusion remained virtually unchanged by glibenclamide or glibenclamide plus theophylline.

The slowly developing and sustained vasodepressor responses to i.v.-infusions of adenosine described above were very similar to those caused by a single bolus i.v.injection of YT-146 in time course and in being antagonized by $6 \mu \mathrm{mol} / \mathrm{kg}$, i.v. of glibenclamide (7). In the previous study (7), the transient vasodepressor responses to single bolus i.v.-injections of adenosine were not antagonized by the same dose of glibenclamide. Thus, as hypothesized previously (7), the vasodepressor mechanisms for adenosine- $\mathrm{A}_{2}$-receptor-mediated vasodepression likely differ between the transient response and the slowly developing response. At least in the dog, the opening of $\mathrm{K}_{\mathrm{ATP}}$ channels appears to be gradually recruited to the vasodepressor mechanisms.

The approximately 6-fold increase in $\mathrm{ED}_{50}$ value for adenosine caused by glibenclamide in the present experiments was very close to the 5.5 -fold increase in $\mathrm{ED}_{50}$ value for YT-146 under similar conditions in the previous study (7). However, the approximately 33 -fold increase in $E D_{50}$ value of adenosine caused by

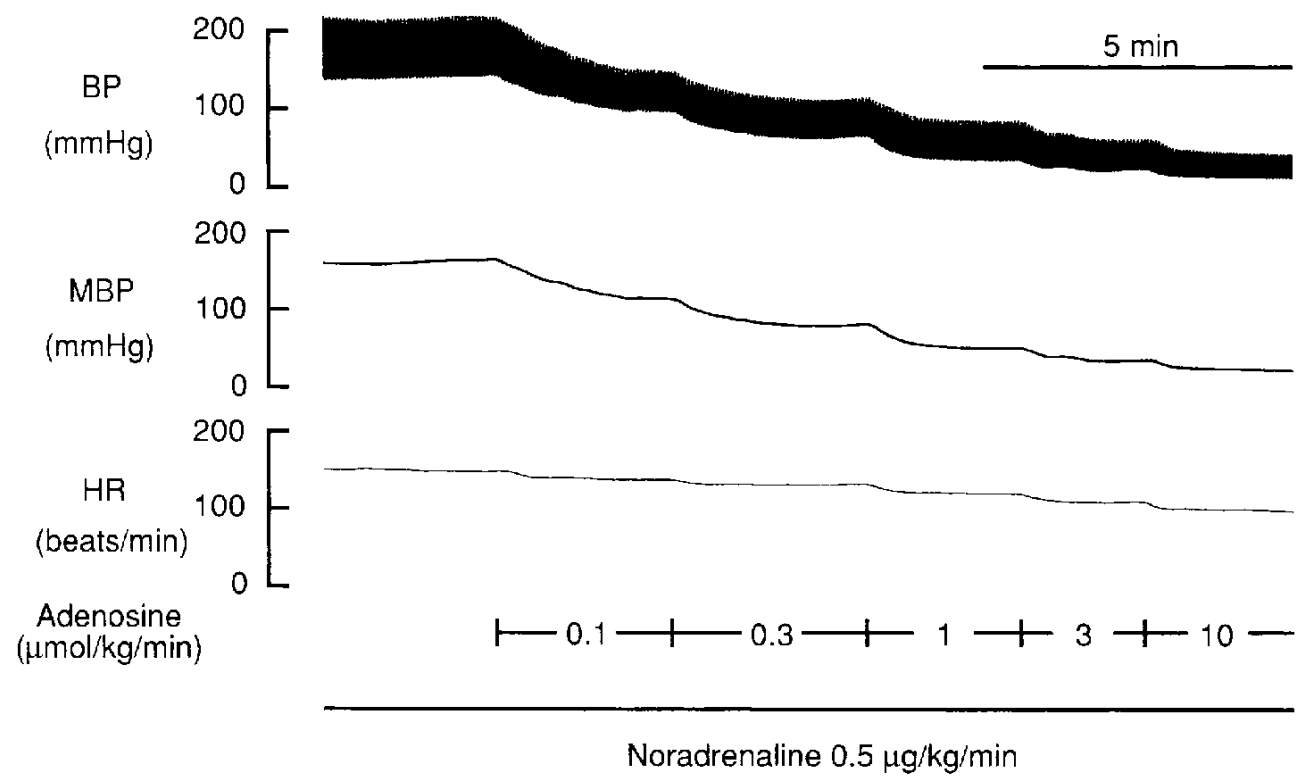

Fig. 1. Effects of i.v.-infusions of adenosine on instantaneous blood pressure (BP), mean BP (MBP) and heart rate (HR). 


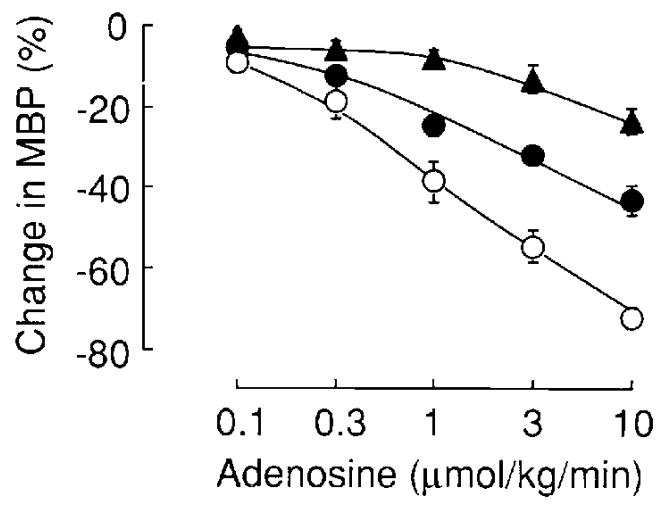

Fig. 2. Dose-response curves for $\%$ change in MBP to i.v.-infusions of adenosine and their modifications by glibenclamide or glibenclamide plus theophylline. Data points represent the mean \pm S.E.M. (O) Control $(\mathbf{n}=5)$. (O) Dogs given glibenclamide $(6 \mu \mathrm{mol} / \mathrm{kg}$, i.v. $(\mathrm{n}=5)$. (A) Dogs given glibenclamide plus theophylline $(30 \mu \mathrm{mol} / \mathrm{kg}$, i.y.) $(\mathrm{n}=4)$.

glibenclamide plus theophylline was much greater than the 6.8-fold increase in $\mathrm{ED}_{\mathrm{so}}$ value of YT-146 that had occurred under similar conditions in the previous study (7). This suggests that the vasodepressor response to i.v.-infusion of adenosine, which is nonselective for adenosine $A_{1}$ and $A_{2}$ receptors, may involve more complicated vasodepressor mechanisms than that to the selective adenosine $\mathbf{A}_{2}$-receptor agonist YT-146. Adenosine has been shown to exert its vasodilator effect by stimulation of $\mathrm{A}_{1}$-receptors, which are linked to guanylate cyclase (11), in addition to an action via adenosine $\mathrm{A}_{2}$-receptors.

\section{REFERENCES}

1 Collis, M.G. and Brown, C.M.: Adenosine relaxes the aorta by interacting with an $A_{2}$ receptor and an intracellular site.
Eur. J. Pharmacol. 96, 61-69 (1983)

2 Kusachi, S., Thompson, R.D. and Olsson, R.A.: Ligand selectivity of dog coronary adenosine receptor resembles that of adenylate cyclase stimulatory $\left(\mathbf{R}_{\mathbf{a}}\right)$ receptors. J. Pharmacol. Exp. Ther. 227, 316-321 (1983)

3 Silver, P.J., Walus, K. and Disalvo, J.: Adenosine-mediated relaxation and activation of cyclic AMP-dependent protein kinase in coronary arterial smooth muscle. J. Pharmacol. Exp. Ther. 228, 342-347 (1984)

4 Cushing, D.J., Brown, G.L., Sabouni, M.H. and Mustafa, S.J.: Adenosine receptor-mediated coronary artery relaxation and cyclic nucleotide production. Am. J. Physiol. 261, H343H348 (1991)

5 Belloni, F.L. and Hintze, T.H.: Glibenclamide attenuates adenosine-induced bradycardia and coronary vasodilatation. Am. J. Physiol. 261, H720-H727 (1991)

6 Schmid-Antomarchi, H., De Weille, J., Fosset, M. and Lazdunski, M.: The receptor for antidiabetic sulfonylureas controls the activity of the ATP-modulated $\mathrm{K}^{+}$channel in insulin-secreting cells. J. Biol. Chem. 262, 15840-15844 (1987)

7 Yoneyama, F., Yamada, H., Satoh, K. and Taira, N.: Vasodepressor mechanisms of 2-(1-octynyl)-adenosine (YT146), a selective adenosine $A_{2}$ receptor agonist, involve the opening of glibenclamide-sensitive $\mathrm{K}^{+}$channels. Eur. J. Pharmacol. 213, 199-204 (1992)

8 Abiru, T., Yamaguchi, T., Watanabe, Y., Kogi, K. and Matsuda, A.: 2-Alkynyladenosine analogs as potent and selective adenosine- $\mathrm{A}_{2}$ receptor agonists. Japan. J. Pharmacol. 52, Supp. II, 92P (1990)

9 Abiru, T., Yamaguchi, T., Watanabe, Y., Kogi, K., Aihara, $\mathrm{K}$. and Matsuda, A.: The antihypertensive effect of 2-alkynyladenosines and their selective affinity for adenosine $A_{2}$ receptors. Eur. J, Pharmacol. 196, 69-76 (1991)

10 Bretschncider, H.J.: Zur pharmakologischen Behandlung koronarer Durchblutungsstörungen. Deutsch. Med. J. 13, 457 - 462 (1962) (in German)

$11 \mathrm{Kurtz}$, A.: Adenosine stimulates guanylate cyclase activity in vascular smooth muscle cells. J. Biol. Chem. 262, 6296-6300 (1987) 